\title{
STD training in Canadian medical schools
}

\author{
Jo-AnNe A DOHERTY, BA(HON), A GORDON JESSAMINE, MB, ChB
}

\begin{abstract}
JA Doherty, AG Jessamine. STD training in Canadian medical schools. Can J Infect Dis 1992;3(3): 118-121.

Овлестіv: The emergence of the acquired immune deficiency syndrome in 1981 and the consequent publicity surrounding sexual behaviour has increased the likelihood that patients will seek medical advice. Sexually transmitted disease (STD) teaching and postgraduate medical programs in Canadian schools of medicine have not been adequately documented. Accordingly, the Laboratory Centre for Disease Control, Department of National Health and Welfare, sought to determine the magnitude and scope of STD training in these schools. Design: A four page questionnaire sought information on preclinical, clinical and residency training in terms of the number of classroom and laboratory hours of instruction, the subspecialty responsible for providing the training, and the clinical 'hands on' experience of the teachers; each respondent was also asked to assess the quality and scope of instruction provided at his/her medical school. Setring/Participants: The questionnaire was mailed to the Dean of each of the 16 schools of medicine in Canada; it was requested that the questionnaire be forwarded to and completed by the person responsible for STD training at the university. REsuLts: Thirteen schools (81\%) completed the questionnaire. Each school indicated that some STD instruction was provided at the undergraduate level; the mean number of hours of classroom instruction was 6.1. Physicians with STD clinical 'hands on' experience were responsible for teaching in 12 schools. Infectious disease residents spent 4 to $80 \mathrm{~h}$ on STDs, while those from other residency programs where STD was not an elective spent 2 to $8 \mathrm{~h}$. Each medical school was asked to provide an evaluation of its program. Only three respondents considered their STD training program adequate. The majority of schools responded that infectious disease residents received sufficient training but the training offered medical students and residents in other programs was less than adequate. The quality of teaching was considered 'excellent' in three schools, 'good' in nine, and 'poorly co-ordinated' in one. Conclusions: There is no simple solution to ensure that every physician in Canada receives sufficient clinical training in STDs. Collaborative and cooperative efforts by federal, provincial and local governments, professional societies, licensing bodies, medical schools, residency programs, STD clinical directors and provincial and territorial directors of STD control, should be encouraged.
\end{abstract}

Key Words: Education, Infectious diseases, Professional training. Sexually transmitted diseases

\section{Formation dispensée par les écoles de médecine canadiennes concernant les maladies transmissibles sexuellement}

Oвлестіғ: A cause de l'émergence du syndrome d'immunodéficience acquise en 1981 et de la publicité qui a suivi sur le comportement sexuel, les patients sont plus enclins à consulter les médecins. Mais on demeure peu informé sur l'enseignement traitant des maladies transmissibles sexuellement (MTS) et sur les programmes médicaux post-universaires offerts au Canada. Le Laboratoire de lutte contre la maladie, Santé et Bien-être Canada, a donc entrepris de remédier à cette lacune. Plan: On a préparé un questionnaire de quatre pages portant sur la formation pré-clinique, clinique et internée des étudiants en médecine - nombre d'heures d'enseignement dispensées en classe et en laboratoire, spécialistes responsables de la formation, expérience clinique/pratique des enseignants; on a également demandé à chaque répondant d'évaluer la qualité et l'étendue de l'enseignement dispensé par sa faculté de médecine. Mrureu/Participants: Le questionnaire a été envoyé au Doyen de chacune des 16 écoles de médecine du Canada; on a demandé qu'il soit confié à la personne responsable de la formation des étudiants dans le domaine des maladies transmissibles sexuellement. Resultats: Treize écoles (81\%) ont rempli le questionnaire, chacune d'elles

Division of STD Control, Bureau of Communicable Disease Epidemiology, Laboratory Centre for Disease Control, Department of National Health and Welfare, Ottawa, Ontario

Correspondence and reprints: Ms Jo-Anne A Doherty, Division of STD Control, Bureau of Communicable Disease Epidemiology. Laboratory Centre for Disease Control. Tunney's Pasture, Ottawa, Ontario K1A OL2

Received for publication May 13, 1991. Accepted July 18, 1991 
indiquant que l'enseignement en matière de MTS était offert au niveau du ler cycle; le nombre moyen d'heures de cours en salle de classe était de 6,1 heures. Les médecins ayant une expérience clinique dans le domaine étaient responsables de l’enseignement dans 12 écoles. Les résidents spécialisés en maladies transmissibles consacraient de 4 à 80 heures aux MTS; la formation était réduite à 2 à 8 heures chez les autres étudiants pour qui les MTS n'étaient pas une matière facultative. Chaque école de médecine devait fournir l'évaluation de son programme. Trois d'entre elles seulement ont estimé que la formation en MTS était adéquate. La majorité des écoles jugent que les résidents spécialisés en maladies transmissibles sont suffisamment préparés mais que la formation offerte aux étudiants et résidents inscrits aux autres programmes laisse beaucoup à désirer. L'enseignement était jugée "excellent" dans trois écoles, "bon" dans neuf cas et "mal coordonné" dans un seul. Conclusions: Il n'existe pas de solution simple garantissant à chaque médecin canadien une bonne formation clinique en MTS. Il faudrait encourager la collaboration et les efforts collectifs parmi les gouvernements fédéral, provinciaux et locaux, les organismes de réglementation professionnelle, les écoles de médecine, les programmes d'internat, les directeurs de cliniques de MTS et les responsables de la lutte contre les MTS dans les provinces et territoires.

$\mathrm{T}$ HE EMERGENCE OF THE ACQUIRED IMMUNE DEFICIENCY syndrome (AIDS) in 1981 and the consequent publicity surrounding sexual behaviour and 'safer sex' practices has increased the likelihood that patients will seek medical advice.

Most physicians have clinical experience in the diagnosis, treatment and management of the traditional sexually transmitted diseases (STDs) - gonorrhea and syphilis - and most are familiar with the effectiveness of the control measures of early detection, appropriate treatment and contact tracing. Although the total number of cases of these STDs has been declining over the previous two decades, for the first time ever females aged 15 to 19 years recorded the highest rate of gonorrhea in 1988 (1). As well, the increasing number of gonococcal strains resistant to penicillin (PPNG) has challenged the clinical complacency of physicians in the treatment of gonorrhea. Many Canadian physicians regard the incidence of $P P N G$ as a minor problem. However, British Columbia experienced an increase in the proportion of PPNG well above the hyperendemic rate of 3.0\% during the first six months of 1990 (2).

Surveillance data on the incidence of gonococcal infection in adolescents and young adults serve as a marker for the most common bacterial genital pathogen in industrialized countries, Chlamydia trachomatis. This pathogen is two to three times more common than gonorrhea and is the major cause of reproductive health problems in women. Chlamydial infection in women is often asymptomatic and, undiagnosed and untreated, it may ascend to the upper genital tract, contributing to pelvic inflammatory disease and its sequelae of infertility, ectopic pregnancy and chronic pelvic pain. In Canada, the incidence of ectopic pregnancy increased from one in 175 to one in 77 between 1977 and 1984, and heralds a need for more rigorous clinical and laboratory scrutiny of this potent pathogen (3). Furthermore, the establishment of the royal commission on new reproductive technologies is testimony to the number of women who are infertile, frequently as a consequence of chlamydia infection. The annual cost to the Canadian health care system of non-AIDS STDs and complications exceeds \$200 million (4).

Viruses which are sexually transmitted, such as human immunodeficiency virus (HIV), human papillomavirus (HPV), and herpesvirus present a special challenge for physicians. Such infections are lifelong and incurable, and may have severe and fatal consequences. Physicians must recognize that control measures for viral STDs differ from those for bacterial STDs in that a greater emphasis must be placed on changing or reducing behaviours which place persons at risk of acquiring an STD.

STDs in children are important indicators of sexual abuse (5). Many physicians do not understand the implications of STDs in prepubertal children, nor do they screen children who are suspected of having been sexually abused for STDs.

STD diagnostic and treatment services and physician training in STDs were considered inadequate even before AIDS became established (6). In the United States, fewer than $10 \%$ of physicians received clinical training in STDs, although one-half of them engaged in subspecialty practices where more than $5 \%$ of their patients had STD related problems (7).

Information on STD teaching and postgraduate medical programs in Canadian medical schools has not been adequately documented. Consequently, the Division of STD Control of the Laboratory Centre for Disease Control sought to determine the magnitude and scope of STD education in these schools.

\section{MATERIALS AND METHODS}

A questionnaire sent to the Deans of the 16 Canadian schools of medicine in 1987 required completion by the person(s) responsible for STD training. The questionnaire was adapted from the one developed by Stamm et al (8). Information was sought on preclinical training (lectures, laboratory experience, classroom and laboratory hours, course affiliation, instructors' clinical experience), and on undergraduate clinical training (number of students instructed, number of hours, clinic setting, mandatory or elective attendance, and the subspecialty responsible). STD training in residency programs was assessed based on the number of residents participating and the hours allocated by each subspecialty. Information on continuing medical education programs involved the number of sessions, 
the number of hours assigned to each session, the target audience and the topics covered. In addition, each respondent was asked to provide a personal evaluation of his or her school's program.

\section{RESULTS}

Thirteen schools (81\%) responded. Each indicated that some STD instruction was provided in the preclinical years. The number of teaching hours ranged from one to 15 (mean 6.1). Where instruction hours exceeded six, infectious disease staff participated, alone or in collaboration with persons from medical microbiology. Physicians with STD clinical ('hands on') experience were responsible for teaching in 12 schools.

Five schools offered laboratory experience for a median duration of $2.6 \mathrm{~h}$. Two schools provided 1 to 2 $\mathrm{h}$ laboratory instruction in the preclinical years; three schools offered it in a third year course on laboratory medicine.

All schools reported that some clinical training was provided or available to undergraduates and residents, through either hospital- or community-based STD clinics or hospital subspecialty clinics.

Eight schools offered undergraduate students clinical experience in a community-based STD clinic (two), a hospital-based STD clinic (four) or both (two); the duration of training ranged from $3 \mathrm{~h}$ (in each of two schools) to four weeks. In the five schools not affiliated with a dedicated STD clinic, electives were available through the infectious disease (four) and primary health care divisions (one).

Two schools required compulsory clinical training at the undergraduate level. The 164 students enrolled in these programs each received an average of 3 to $4 \mathrm{~h}$ clinical instruction. In the six schools affiliated with a dedicated STD clinic and where STD clinical training was not mandatory, approximately $28 \%$ of eligible students (104 of 361) undertook the elective. Ten per cent of students chose STD clinical training as an elective in schools which offered training through a subspecialty.

Nine schools provided data on residents' STD clinical training. In six, residents in certain subspecialties were required to undertake this training. Included were infectious disease residents in four schools, community medicine, family medicine and internal medicine residents in two schools, and medical microbiology, obstetrics/gynecology and pediatric residents in one school each. In the three remaining schools, STD clinical training was available as an elective. Infectious disease residents spent 4 to $80 \mathrm{~h}$ on STDs, while those from other subspecialties spent 2 to $8 \mathrm{~h}$. Information on elective STD clinical programs for residents in other specialties was limited, but ranged from 2 to $20 \mathrm{~h}$.

Twelve respondents provided a personal evaluation of their program. Ten were infectious disease staff members, one was an internist and in one instance the respondent's qualifications were not known. Only three respondents considered their STD training program adequate. The majority felt that infectious disease residents received sufficient training, but that training offered to medical students and residents in other subspecialties was less than adequate. The quality of teaching was considered 'excellent' in three, 'good' in nine, and 'poorly co-ordinated' in one. One respondent commented that any expansion or extension of STD experience should not be undertaken at the expense of other infectious disease training.

All respondents stated that they offered continuing medical education sessions on STDs. The number of sessions offered per annum ranged from one to 10 . The average number of hours per STD session was 3.8. Infectious disease was the discipline cited most frequently (nine times) as being responsible for the STD portion, followed by medical microbiology (four), internal medicine (three), obstetrics/gynecology (two) and family medicine (one). The frequency of STD topics was update (six), diagnosis (four), overview (three), treatment (three) and prevention (one). Individual STD topics addressed were chlamydia (10), gonorrhea (nine), herpes (seven), pelvic inflammatory disease (seven), human papillomavirus (three), nonspecific vaginitis (two) and chancroid (one). AIDS was cited 10 times as a course topic, although not exclusively as an STD. The target audiences for the continuing medical education sessions were general practitioners (12), obstetricians/ gynecologists (three), dermatologists (two) and infectious disease specialists (one). Pediatricians, surgeons, nurses, pharmacists, social workers and 'any physicians' were each cited once.

\section{DISCUSSION}

The objective of this study was to determine the extent to which Canadian medical schools prepared undergraduates, residents and other physicians in the provision of diagnostic, treatment and educational services for STD.

There are no established Canadian criteria against which medical schools' STD programs might be measured. In the United States, a commissioned review committee recommended that "by 1990, all medical schools shall establish clinical staff affiliations with public or private STD treatment facilities so that all medical students and physicians-in-training will receive a minimum of 20 hours of supervised clinical experience" (9).

These survey results indicate that, apart from certain residency programs, Canadian medical schools provide considerably less instruction than the minimum number of hours recommended in the United States. Indeed, respondents felt that more time and better quality STD training was needed in 11 of the 13 schools that responded.

The competition for teaching time in medical schools provides little opportunity to add new topics or extend 
time allocated to old ones. Adler and Wilcox (10) found an actual reduction in STD instruction time in British medical schools, despite the presence of a genitourinary medicine subspecialty and the recognition of increasing STD-associated complications.

In Canada, the provision of additional STD training at the undergraduate level must be reviewed. The need for adequately trained primary health care physicians persists, and residency programs require upgrading. These deficiencies have stimulated alternative and supplementary approaches to medical school/residency STD training, but their effectiveness has not been evaluated. Supplementary approaches have included the development of national standards by the Department of National Health and Welfare for the diagnosis, management and treatment of STDs $(11,12)$, and for examination of children suspected to have been sexually abused (5), as well the provision of at least one provincially funded STD training program for physicians and nurses.

The skills required by physicians to adequately diagnose, manage and treat STDs are simple and straightforward. Such skills should focus on history taking, the physical examination, obtaining appropriate specimens and counselling skills. Videos supplemented with written handouts may represent a cost-effective method of teaching these skills. Physicians, the health care system and the community at large should place greater emphasis on preventive behaviours such as abstinence, reduction in number of casual partners and con-

ACKNOWLEDGEMENTS: This project was recommended by the Expert Interdisciplinary Advisory Committee on Sexually Transmitted Diseases in Children and Youths (EIAC-STD) and funded by the Child Sexual Abuse Initiative of the Department of National Health and Welfare.

\section{REFERENCES}

1. Jessamine AG, McHale KA. Trends in gonorrhea in Canadians 15-24 years of age, 1981-1988. Can Dis Weekly Rep 1989;15:253-4.

2. Rekart ML. Penicillinase-producing Neisseria gonorrhoeae (PPNG) in British Columbia. Can Dis Weekly Rep 1990;16:245-6.

3. Health and Welfare Canada. Sexually transmitted diseases in Canada 1986. Can Dis Weekly Rep 1988; 14:(Suppl 1E): 1-22.

4. Todd MJ, Estany A, McLaren R. Costs of pelvic inflammatory disease and associated sequelae in Canada. Can Dis Weekly Rep 1988;14:206-8.

5. Sacks D. 1989 Canadian guidelines for health care providers for the examination of children suspected to have been sexually abused. Can Dis Weekly Rep 1989;15(Suppl 3):1-16. dom use, as a major strategy to reduce the incidence of STDs in Canada.

There is no simple solution to ensure that every physician in Canada receives sufficient clinical training in STD. Collaborative and cooperative efforts by federal, provincial and local governments, professional societies, licensing bodies, medical schools, residency programs, STD clinical directors and provincial and territorial directors of STD control should be encouraged. Continuing medical education sessions, ad hoc seminars and scientific conferences have a role to play in providing up-to-date information, but they cannot match 'hands on' experience and training.

Professional societies should accept a leadership role in professional STD training. They qualify because of their clinical interest, expertise in diagnosis, treatment and management and, in some instances, because of their apparent willingness to accept teaching responsibilities. The extent and duration of STD training for the various levels of clinical practice, and to qualify physicians as subspecialty fellows and certificants, should be recommended by peers.

Licensing bodies should shoulder some of the responsibility, as well, to ensure that physicians who are licensed to practice medicine are adequately trained in STDs. The examinations of the Medical Council of Canada, the Royal College of Physicians and Surgeons, and the College of Family Physicians should ensure that questions reflect, in scope and magnitude, current epidemiology and practice standards for STDs.

6. Judson FN, Boyd WA. The Denver sexually transmitted diseases prevention/training centre: A two-year performance evaluation. Sex Transm Dis 1982;9:183-7.

7. Cates W. How justifiable is public support of sexually transmitted disease clinical services? JAMA 1986:255:1769.

8. Stamm WE, Kaetz S, Holmes KK. Clinical training in venereology in the United States and Canada. JAMA 1982:248:2020-4.

9. Work Group on Sexually Transmissible Disease. Conference on preventing disease, promoting health Objectives for the nation: Sexually transmissible diseases. Sex Transm Dis 1979;6:273-7.

10. Adler MW, Wilcox RR. Teaching of genitourinary medicine (venereology) to undergraduate medical students in Britain. Br J Ven Dis 1981;57:170-3.

11. MacDonald NE, Bowie WR, Read S. 1988 Canadian guidelines for the treatment of sexually transmitted diseases in neonates, children, adolescents and adults. Can Dis Weekly Rep 1988;14(Suppl 2):1-19.

12. Bowie WR, MacDonald NE. 1989 Canadian guidelines for the diagnosis and management of sexually transmitted diseases, by syndrome, in children, adolescents and adults. Can Dis Weekly Rep 1989:15(Suppl 1):1-33. 


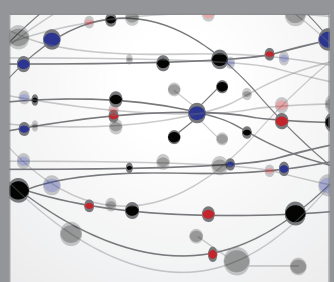

The Scientific World Journal
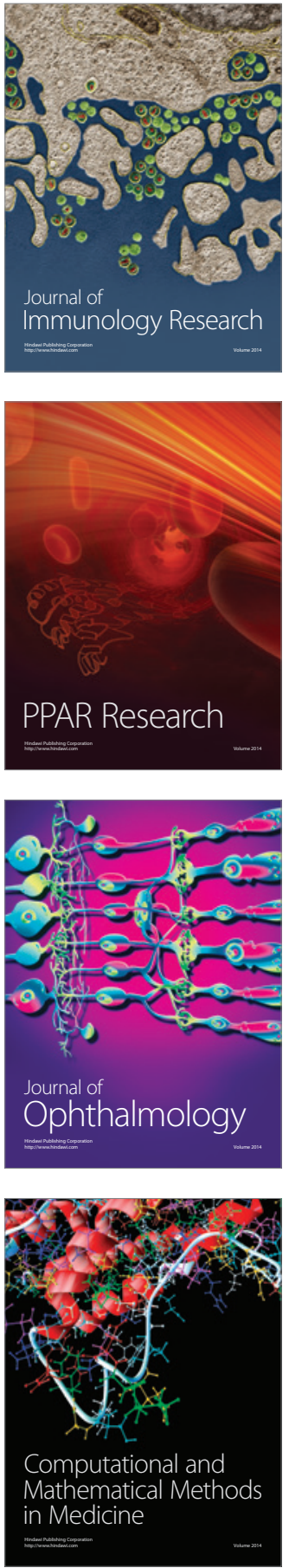

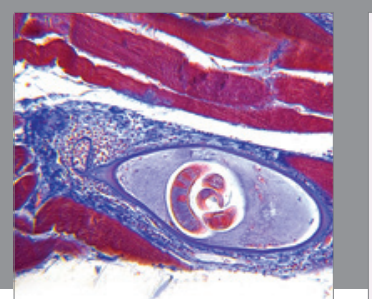

Gastroenterology Research and Practice

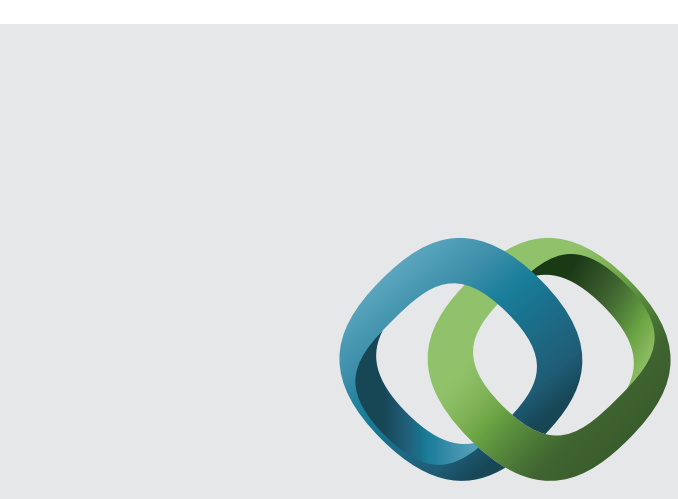

\section{Hindawi}

Submit your manuscripts at

http://www.hindawi.com
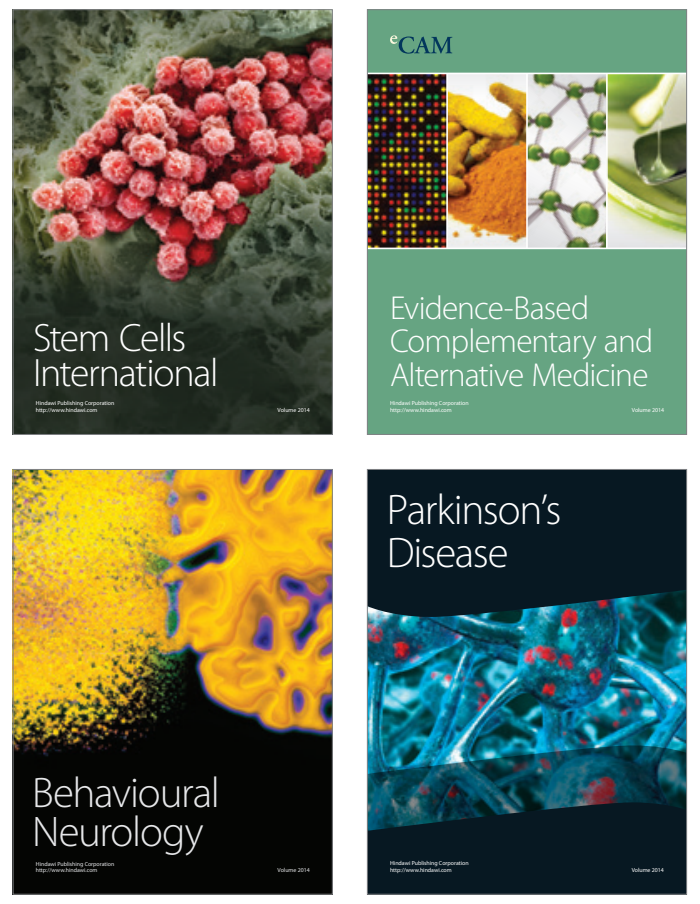
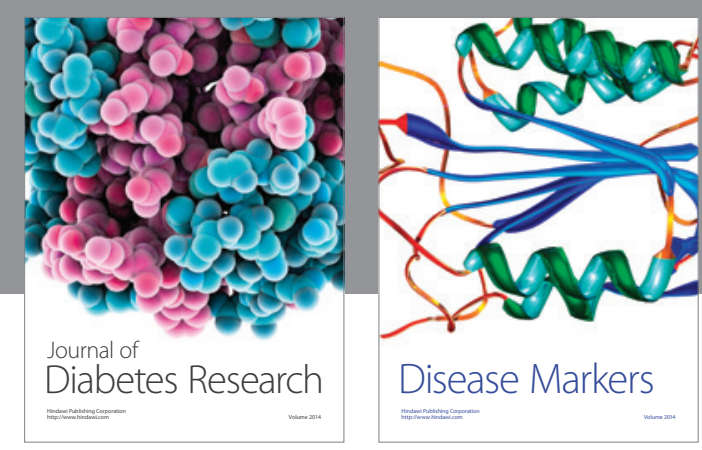

Disease Markers
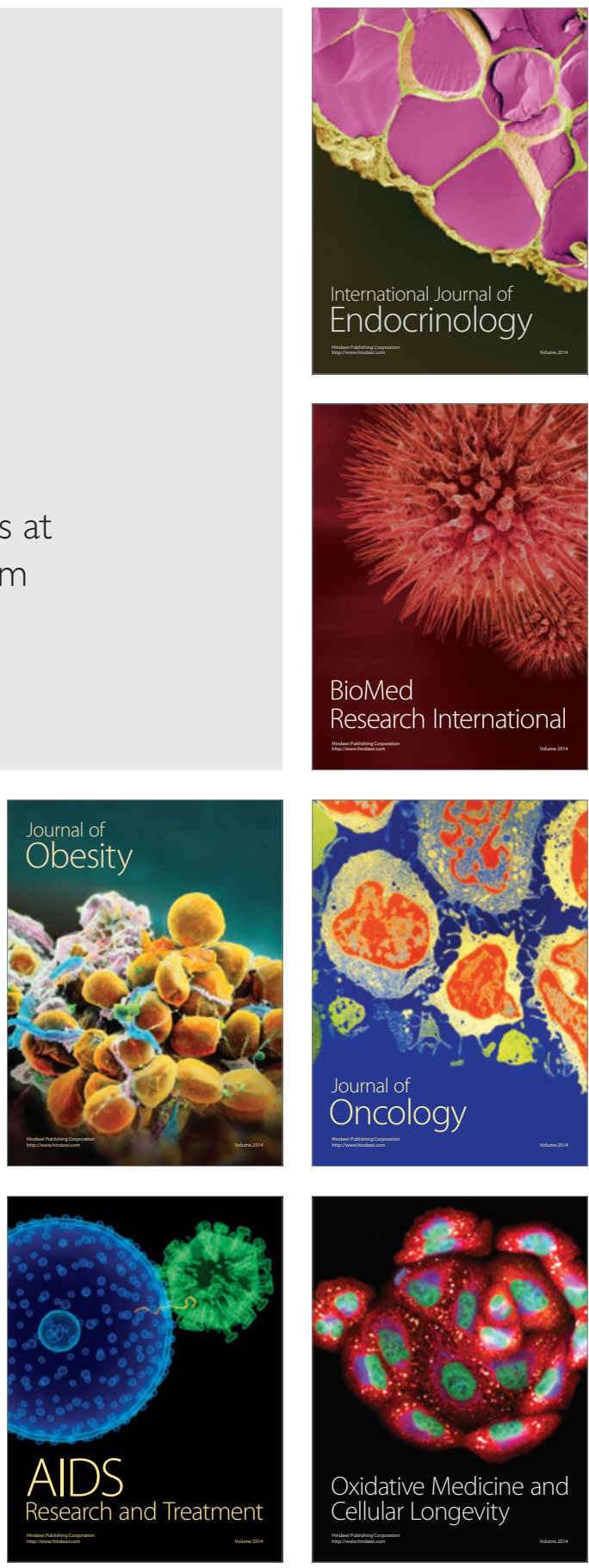